\title{
Modernity in Two Great American Writers' Vision: Ernest Miller Hemingway and Scott Fitzgerald
}

\author{
Fahimeh Keshmiri ${ }^{1}$ \& Shahla Sorkhabi Darzikola ${ }^{2}$ \\ ${ }^{1}$ English Department, Farhangian University, Isfahan, Iran \\ ${ }^{2}$ English Department, Payame Noor University, Firozkooh, Tehran, Iran \\ Correspondence: Fahimeh Keshmiri, English Department, Farhangian University, Isfahan, Iran. E-mail: \\ Keshmiri_86@yahoo.com
}

Received: August 18, 2015 Accepted: February 11, 2016 Online Published: February 14, 2016

doi: 10.5539/elt.v9n3p96

URL: http://dx.doi.org/10.5539/elt.v9n3p96

\begin{abstract}
Scott Fitzgerald and Ernest Hemingway, American memorable novelists have had philosophic ideas about modernity. In fact their idea about existential interests of American, and the effects of American system on society, is mirrored in their creative works. All through his early works, Fitzgerald echoes the existential center of his era. Obviously, we recognize Hemingway's vision of modernity in formation of his own philosophies of life, death, and art in what is known as Hemingway's characteristic philosophy, Code, and Code Heroes. In this article, among the numerous characteristics illuminating these two writer's vision of America, the main themes of their foremost works have been analyzed with regard to some Critic's viewpoints regarding these two, literary masters. Critics see Fitzgerald both as a chronicler, and a perceptive social critic who is totaling the "dilemmas of philosophy" in his art. Indeed, what in American critics' view is a fatalistic philosophy, with the darker side of life, existentialist critics consider as a prophetic optimism and an absurdist vision that places Hemingway in the ranks of a "guide "prophet of those who are without faith".
\end{abstract}

Keywords: Scott Fitzgerald, Ernest Hemingway, existentialism, America, Twenty Century, modernity

\section{Introduction}

Fitzgerald and Hemingway portray an image of the mental experience of being American that origins from the American existential basics in the early twenty century. Actually, these two writer's philosophic ideas about modernity, and their existential concerns with the results of an oppressive American system on the individual and the culture, echo through their cultural criticism and literary works. Considerably, critical researches of Fitzgerald and Hemingway generally consider these writers as unaware of philosophy; although some letters, library documents, and the writer's works reveal that these two writers were plainly versed in the philosophic discourse of their era.

Critics frequently markdown philosophic works in Hemingway's reading collection, mentioning that Hemingway presumably never read them; and, "Fitzgerald's copy of H. L. Mencken's The Philosophy of Frederick Nietzsche, a work his interviews and letters disclose he highly esteemed that Nietzschean ideology had a reflective influence on his thinking and works in his first half of twenties, are hardly ever well thought-out in critical studies of Fitzgerald's tenet of works" (Bruccoli, 2004). So far, because the decade of the twenties was philosophically explosive, Fitzgerald and Hemingway, who both read a diversity of works to create their art, have noticed the main thinker currents of their time and as they have remarked every aspect of culture in their literary works, their awareness of the philosophic present of their era are proved. Yet, European philosophies were appropriated to American interests, in the academic rounds, in social and cultural criticism, and in some of America's most well-known magazines and journals.

Significantly, Fitzgerald and Hemingway have the most fluent existential vision of modernity and take responsibility for totaling the philosophical dilemma of it. Yet they are two renowned literary voices whose impacts are felt by several authors and are still felt nowadays.

\subsection{Literature Review}

Fitzgerald and Hemingway's literary art takes shape as a vision stimulated by philosophers of their era. Some scholars believe Fitzgerald's writing is influenced by the philosophic currents of his time. Fitzgerald scholar 
Ullrich, David (1999) in "Memorials and Monuments: Historical Method and the (Re) Construction of Memory in F. Scott Fitzgerald's 'The Ice Palace'”, p. 2, identifies the existentialist desire in this writer's focus on identity and cultural memory in his early works. Foster, Richard (1968), in his book: "Mailer and the Fitzgerald Tradition.", p. 219, mentions that "Fitzgerald's existential vision of modernity positions him as the first modern American author to interpret American experience existentially".

In comparison, so many researchers have described Hemingway's philosophy as existential-oriented echoed in his Code Heroes. Kvam, Wayne (1973), in "Hemingway in Germany" p. 154, notes that "existentialist critics naturally felt immediate kinship with a writer who recognized death as the only absolute", what he considers as a major theme of Hemingway's early works. Killinger John (1960), in "Hemingway and the Dead Gods", mentions that Hemingway's tremendous sense of contemporaneity, what reflected the philosophical movement of his era, made him famous initially. Castillo-Puche Jose (1968), in his book by the name of "Hemingway Entre La Vida Y La Muerte" claims the Spanish bullfight as essential to Hemingway's formation of a coherent philosophy. Broer Lawrence R. (1973), in "Hemingway's Spanish Tragedy", insightfully notes that "in the image of the matador" Hemingway "found a symbol of the best a man can be in a violent and irrational world-a model of manhood and integrity after which he would pattern his major fictional heroes". Beegel, Susan F. (1990), "That Always Absent Something Else" p. 75, mentions that the basis of Hemingway's philosophy concentrates on individual experience, feeling and question of individual "existence".

\section{Research Methodology}

As a first step, the researcher read books and papers that present the key issues concerned in Philosophical ideas in 20 century. In the second step, the researcher read biographical works on Ernest Hemingway and F. Scott Fitzgerald's life to get a clear picture of their background, their development as writers and their response to the period they lived in. The researcher, in the third step, did a comprehensive reading of Hemingway and Fitzgerald's foremost short stories and novels. As the last step the researcher studied critical works that analyze and reflect the thematic, philosophical, social, cultural and intellectual preoccupations that were revealed in Hemingway and Fitzgerald's life and works. Furthermore, in this research the various types of materials has been used about these two great writer's works and era to establish unbroken connection between their time and literary heritage. In accomplishing this study, intrinsic approach and also apply descriptive analytical methods are used which combine with interpretation.

\section{Results and Discussion}

\subsection{Modernity in Fitzgerald's Vision}

Fitzgerald is considered as "the spokesman of the Jazz age and the lightly philosophizing young America, by the end of 1922" (Bruccoli, 2004). He names his age the Jazz Age and describes it like no other writer of his time. The vision of modernity this writer presents in his early works makes him famous as the chroniclers of Jazz Age America, and the critics recognizing the existentialist whim in his work (specially in The Great Gatsby and Fitzgerald's World of Ideas), consider him as a chronicler and a perceptive social critic who is working out the dilemmas of philosophy in his art. Ronald Berman argues that "the Nietzschean philosophy has influenced Fitzgerald's art and thought and he attributes this influence to American critic H.L Mencken and his translation of Nietzschean philosophy to an American context" (Berman, 2001).

Fitzgerald scholar David Ullrich, discusses that "there is an existentialist impulse in Fitzgerald's early works which embodied in his existentialist critique of America's tendency to erect memorials and monuments as a way of shaping cultural memory, regional and personal identity, and thus assuring conformity and thwarting the possibility of envisioning individuality" (Ullrich, 1999). Fitzgerald shaped the identities of the personality and the nation through his early interest in America's creation of mythologies, and it forms the foundation of his early existential vision of modernity.

Fitzgerald's compound idea places him as a speaker and an existentialist. During his early works, Fitzgerald deals with the existential core of his era by presenting the difference between American ideals and traditionalist standards of the culture overall. "Critics, for instance regard The Ice Palace as a work to criticize the American political and social structures what aims to make individuals' devotion to general values and ensure individuals' conformity" (Ullrich, 1999). In The Diamond as Big as the Ritz, The writer tries to illustrate the America's emphasis on the significance of one's prosperity, which had become one's major attempt, more significant than human life. While critiques discover various sides of American culture in Fitzgerald's stories, they reveal that in this writer's existentialist view, this culture is leading the individuals to death and consequently to the ultimate death of American culture. 
Fitzgerald reveals this belief in his novels This Side of Paradise (1920) and The Beautiful and Damned (1922) repeatedly through creating broken and unable characters, what Fitzgerald considers as the collapse of individuals, morally and bodily. Yet, in this author's distrustful vision of modernity, we can see an expectation for the individual and American culture. In his vision, firstly an individual should come to a deep understanding of self and world. For instance, at the end of The Ice Palace, Sally Carrol Happer comes to an existential self awareness and This Side of Paradise ends with Armory Blaine's statement about his self awareness. In Diamond, Kismine and John come to consciousness that love and humanity pleases us more than riches and also they come to an awareness of the death of the individual. Indeed, The Beautiful and Damned ends with Anthony Patch's proud vision of himself. In Ullrich's view, Fitzgerald's early works reveal his anatomy of a "complex philosophy of culture," and his critique of American culture in his afterward works. Actually, at 1922 planning to write The Great Gatsby, he claimed to Maxwell Perkins that he wanted to write something new, "in fact he had decided to write something different from his own works and the other artistic endeavors of his contemporaries" (Lehan, 1990). Soon at 1924, Fitzgerald in an interview declares a change in the rational and literary climate of his time in Gatsby. He advocatesthat he was both well-informed of the American cultural discourse of his time and that this familiarity was sufficient to literary groups; it occupied American community discourse. Long believes that "it is through Fitzgerald's writing of Gatsby, that he finds his vision" (Long, 1979).

As a multifaceted unify of politics, history, religion, social issues, and philosophy, Fitzgerald's vision in Gatsby shows the cultural and philosophic dilemmas of his time, and separates him from his contemporaries. For instance, the postwar writers were inclined to write pessimistically about the American culture, and unrestricted individual freedom, but Gatsby different from Fitzgerald's early works, describes this culture as a not authentic one.

Additionally, what makes Gatsby a different work is "his presentation of the dilemmas of philosophy which are affected by the philosophic discourse of his time and became more complex in the novelistic form of Gatsby, in anecdotes of social life" (Berman, 2001). We can find this complex vision of modernity in this novelist's optimistic-absurdist idea about current experience. As Morris claims, this view point places him as "the first American to formulate his own philosophy of the absurd, a philosophy that takes shape during Fitzgerald's conscious attempt to write something new, something different from the works of his contemporaries and from his own early artistic endeavors, something contemporary that also captures the dilemmas of philosophy and presents a remedy for living in Jazz Age modernity" (Morris, 1963).

Even though Fitzgerald's philosophic idea origins from Nietzsche's existentialism, we cannot have a complete understanding of his absurdist idea by trusting solely on a Nietzschean frame. Actually, Nietzsche is a distinct section of Nick's story and Fitzgerald's complicated philosophy. Finally, Nick recognizes that Gatsby's trust is a faith in the absurd. It is Gatsby's committal to Daisy, his trust, and his hope, that revives Nick's faith, and shapes the foundation of the absurdist vision the writer shows in Gatsby.

In order to comprehend Fitzgerald's absurdist vision of his era we should consider Gatsby as an outcast to the Nietzschean civilization, Nick envisions as his own. Gatsby threatens his life and his creation of Jay Gatsby to gain affluence for achieving Daisy, an impossible desire. For Nick, it is Gatsby's optimism and reliance that makes his vision diverse from his own. But in Fitzgerald's vision "hope keeps the world beautifully alive and this vision forms the basis of his absurdist vision" (Lehan, 1990). It is Gatsby's hope, faith, courage and the valid liveliness of his enthused spirit that Nick respects and separates Gatsby from the others. Yet, Gatsby believes that the American spirit can save the entity and culture from the corruption, the death of what Fitzgerald seems to be exclusively American.

As a result, "Gatsby exemplifies Fitzgerald's optimistic vision for the individual: that hope, faith, commitment, and courage will keep the world beautifully alive" (Lehan, 1990). In Nick's vision, it is exclusively American spirit in Gatsby that is liable for allocation with his generation, although the bodily personification of this spirit is damaged by the irresponsible, it will be alive in the memories of his generation.

Mailer mentions, "During Fitzgerald's creation of his own rational outlook of American culture and the individual's position in culture, he puts his philosophy in action through Gatsby with the purpose of describing a nation's vision of itself' (Mailer, 1966). Fitzgerald aims to clarify that the American culture ruins individuals and it is just hope and responsibility that save us. For Nick, Gatsby's hope, reliance, bravery, and promise are creditable. As Nick believes Gatsby has an absurdist trust in the impossible; but it is worthless. Though Fitzgerald trusts on hope, he also supposes that we must break all fantasies, see the real world and try to grow our own vision. In real, what instigates Nick to promote his own creative spirit is Gatsby's liveliness and wish, and it is through creating Gatsby that he becomes an artist, who proposes an art of living in modern era. 


\subsection{Modernity in Hemingway's Vision}

As Madariaga declares, "Hemingway's image of modernity is generally accredited to the formation of his own philosophies of life, death, and art in what has been known as his Code and Code Heroes" (Madariaga, 1961). So many critics have mentioned that the growth of Code Hero is apparent in this writer's early works and they have introduced him as an existentialist. John Killinger believes that Hemingway uses the theme of death in his early works to reduce the problem of existence to its lowest common denominator. Wayne Kvam, remarks that "existentialist critics naturally felt immediate kinship with a writer who recognized death as the only absolute, and he used it as a main theme of his early works" (Kvam, 1973). Jose Castillo-Puche states that after this literary master saw the first bullfight in 1923, "the bullfight was to remain fixed in him and indelible, the basis of his elemental philosophy which he would carry with him throughout his life" (Broer, 2002). In fact matador is the symbol of the best man in an irrational world.

In about nine years before Hemingway's publication of his, Death in the Afternoon, Hemingway publishes many articles and essays about the Spanish bullfight in different forms. They were: Bullfighting, Sport, and Industry, World Series of Bull Fighting a Mad, Whirling Carnival, Tancredo is Dead, Maera Lay Still, and his poetry, The Soul of Spain, and Part Two of the Soul of Spain. However, Miriam Mandel states that "Hemingway's first piece on the Spanish bullfight was written before he saw his first bullfight. It was The First Matador Got the Horn, that reads like an objective, journalistic eyewitness account, but it is a mix of hearsay, imagination, and reading, a crafted exercise in voice and point of view" (Mandell, 2004). In 1924 Hemingway produced more bullfight poetry. The bullfight in Hemingway's creative writing includes The Undefeated (1925), The Sun Also Rises (1926), Banal Story (1927), and The Mother of a Queen, which was published in 1933 (Mandel, 2004).

In 1923-1932 Hemingway takes the bullfight to America to introduce Spanish culture to community; he illustrates the American expatriate experience in Paris and the war in his works. In real, Hemingway finds Spain culture different from other cultures of the world. Spain is a country, with a national spirit, which hasn't experienced the World War I and is free from the expatriates and renewal that in Hemingway's vision had spoiled his own local land. Hemingway regards America completely different from Spain, where the ethical principles hold meaning for the individual. Hemingway finds a lost generation disillusioned by the traditionalist values of American culture as the dilemmas inherent in Americans. What he finds in Spain is mutineer, the free spirit, the performer, who is distinguished through the Spanish bullfight. This country tries to promote the growth of the personality and cherishes their culture and philosophy of life and death.

At this time Hemingway starts writing Death in the Afternoon, which is considered as his mistrust of his own culture and has brought him to a profound admiration of the sacred authority of Spain. This novel possessed all the essential features of a genuine culture that America didn't. Its standards including credit, honesty, bravery, self-esteem and pride are firmly embodied in "pun donor". This culture faced death day by day with a liveliness of spirit which was indispensable to the existence of the personality and a nation. "The basis of this philosophy, look realistically at war and death, and... abandon all romantic notions of them, concentrates on individual experience and feeling" (Beegel, 1988).

Death in the Afternoon is considered as a superior voice of an American experience narrator for modern era whose crucial point is the human existence. Hemingway's existentialism and his rational view of life take shape in this novel. He believes that individuals must focus on their own entity. He illustrates a philosophy of existence in the route of death and matador is created as a symbol. He is only expected to do his best by performing admirably in the bull ring. Hemingway asks readers to see clearly and create their own principles and judge what is good and what is evil and they must see their own feelings and affecting reactions as applicable. All in all he insists that readers must take responsibility for their own insights, manner, ethics and judgment and actions, indeed in order to live sincerely, one must encounter the reality of death with sincerity or pun donor. Moreover, "what American critics often regard as a defeatist philosophy, existentialist critics see as a visionary sanguinity and an absurdist vision that places this writer in the ranks of a guide for his generation" (Kvam, 1973). Hemingway's philosophy is an absurd one, "through this philosophy the individual distinguishes that life must be lived with fervor, passion, lucidity and purpose since death may come at any moment" (Kierkegaard, 1993). In Hemingway's vision, in order to be everlasting, we should find the meaning of life, live with it, and renovate this promise continuously. We must have bravery and reliance encountering the death to hand over a purpose for our lives, as matador and Hemingway did. Hemingway's absurdist philosophy of life finds its way through the matador's unification of existence and fatality while the morals of Hemingway's generation are lost.

\section{Conclusion}

Significantly, among so many literary masters in 20 century, Fitzgerald and Hemingway possess the most 
expressive existential visions of their time and they have been known as two of the most imperative literary voices whose after effects are felt by some authors and today. Fitzgerald was the authoritative voice of a generation. He is the writer who names his era, the Jazz Age and describes different aspects of this age in detail through his artistic works, like no other writer of his time. Although the vision this writer mirrors in his early works from modernity makes him famed as one of the most imperative chroniclers of Jazz Age America, critics declare that he can be considered both as a chronicler, and as an astute social critic interested in totaling the predicaments of philosophy in his creative work. The characters in The Great Gatsby and Fitzgerald's World of Ideas, are working out a dilemma of American philosophy.

The existentialist whim is noticeable in Fitzgerald's initial writings, where his center of attention is self and cultural reminiscence as socially created. Some critics consider this writer's original interest in formation of mythologies in America, as the basis of his existential vision of modern era. In real, this vision causes his reputation as the first American author in modern time who construes American experience existentially. Among this author's diverse literary works, The Ice Palace is regarded as a critical writing about the political and social structures of America. In The Diamond as Big as the Ritz, he tries to well illustrate the importance of affluence in American society more than human life. This sensation is reflected in his early novels This Side of Paradise and The Beautiful and Damned again through creating bodily and mentally broken characters, what Fitzgerald portrays as the symbols of a corrupt culture.

In comparison, Hemingway seeks to reflect his vision of modern time in his works through the formation of his "Code" and his "Code Heroes". Many critics believe that this author repeatedly utilizes the theme of death in his early works to weaken the problem of existence. They consider the Spanish bullfight as indispensable to Hemingway's formation of philosophy. He published three essays and poetry and prose on the bullfight.

Hemingway finds Spain, a country with a rich and vital culture, which has preserved its traditionalist values. This feature causes this country to be served as a contrast to America where the morality and entity is ruined. In Death in the Afternoon Hemingway portrays his despoiled culture with the lost identity and he tries to admire the spiritual superiority of Spain for its distinctive culture. In the act of writing Death in the Afternoon, he was considered as the spokesman philosopher for modern era whose focus is human existence. All in all, Hemingway believes that readers must take responsibility for their own insights, morality, beliefs and actions and he proposes the readers to see, judge, and feel in a right way. He wrote the Spanish bullfight, to promote individual's awareness of their own existential position in life, as towards death. One must face the reality of death with earnestness. In Existentialist critic's vision, this philosophical vision is an absurdist one that makes him famous as a "prophet of those who are without faith".

\section{References}

Allen, E. L. (1930). Kierkegaard: His Life and Thought. London: S. Nott.

Beegel, S. F. (1988). Hemingway's Craft of Omission, Ann Arbor. Michigan: UMI Research Press.

Berman, R. (2001). Fitzgerald, Hemingway, and the Twenties, Tuscaloosa: University of Alabama Press.

Broer, L. R. (1973). Hemingway's Spanish Tragedy. University of Alabama Press.

Broer, L. R. (2002). Hemingway and Women: Female Critics and the Female Voice. Tuscaloosa: University of Alabama Press.

Bruccoli, M. J. (1974). Apparatus for F. Scott Fitzgerald's The Great Gatsby. Columbia: University of South Carolina Press.

Bruccoli, M. J. (1996). Scott Fitzgerald on Authorship, Columbia: University of South Carolina.

Bruccoli, M. J. (2004). Conversations with F. Scott Fitzgerald. Jackson: University Press of Mississippi.

Castillo-Puche, J. (1968). Hemingway Entre La Vida Y La Muerte. Barcelona: Edicione Destino.

Foster, R. (1968). Mailer and the Fitzgerald Tradition, pp. 219-230. http://dx.doi.org/10.2307/1345162

Kierkegaard, S. (1993). At a Graveside. Three Discourses on Imagined Occasions. Ed. and Trans, New Jersey: Princeton University.

Kvam, W. (1973). Hemingway in Germany. Athens: Ohio UP.

Lehan, R. (1990). The Great Gatsby: The Limits of Wonder. Boston: G. K. Hall \& Co.

Long, R. E. (1979). The Achieving of the Great Gatsby, F. Scott Fitzgerald, 1920-1925, Bucknell University Press. 
Mailer, N. (1966). Cannibals and Christians. New York: The Dial Press.

Mandell, M. B. (2004). A Companion to Hemingway's Death in the Afternoon. New York: Camden House.

Madariaga, S. (1961). The World Weighs a Writer’s Influence: Spain. Saturday Review, 44, 18.

Ullrich, D. W. (1999). Memorials and Monuments: Historical Method and the (Re) Construction of Memory in F. Scott Fitzgerald's 'The Ice Palace, Studies in Short Fiction.

Willingham, K. G. (2002). The Sun Hasn't Set Yet. Tuscaloosa: University of Alabama.

\section{Copyrights}

Copyright for this article is retained by the author(s), with first publication rights granted to the journal.

This is an open-access article distributed under the terms and conditions of the Creative Commons Attribution license (http://creativecommons.org/licenses/by/3.0/). 